\title{
Environmental Knowledge Management of Finnish Food and Drink Companies in Eco-Efficiency and Waste Management
}

\author{
Momir Beljić, Virgilio Panapanaan, Lassi Linnanen, \\ and Tuomo Uotila \\ Lappeenranta University of Technology, Lappeenranta, Finland
}

momir.beljic@lut.fi Virgilio.Panapanaan@lut.fi Lassi.Linnanen@lut.fi Tuomo.Uotila@lut.fi

\begin{abstract}
Environmental knowledge management helps organizations to achieve their environmental, business, and economic goals. This paper, through the analysis of semi-structured interviews from 11 Finnish food and drink companies, presents how they acquire, share, create, use, and accumulate their environmental knowledge eco-efficiency and waste management from a product life cycle perspective. The findings indicate dominance of tacit over explicit knowledge approaches and greater development of knowledge on raw materials compared to energy efficiency and waste management. Learning by doing, learning from others, formal and informal meetings, measuring and optimizing production parameters are the most important activities in reducing environmental impacts and increasing eco-efficiency. The paper identifies two more findings relating to gaps in knowledge sharing and retention and it proposes some solutions how to overcome them. The main contribution of the paper is demonstration of the life cycle and knowledge management approach that could help companies to identify and understand their eco-efficiency and waste management aspects. Furthermore, this paper outlines how companies could integrate these aspects into their organizational and technological structure.
\end{abstract}

Keywords: Environmental knowledge management, life cycle perspective, waste management, energy efficiency, raw materials

\section{Introduction}

Various tools for environmental management (EM) exist but few of them integrate the product life cycle perspective and the knowledge management (KM) approach. The life cycle perspective

Material published as part of this publication, either on-line or in print, is copyrighted by the Informing Science Institute. Permission to make digital or paper copy of part or all of these works for personal or classroom use is granted without fee provided that the copies are not made or distributed for profit or commercial advantage AND that copies 1) bear this notice in full and 2) give the full citation on the first page. It is permissible to abstract these works so long as credit is given. To copy in all other cases or to republish or to post on a server or to redistribute to lists requires specific permission and payment of a fee. Contact Publisher@InformingScience.org to request redistribution permission. is an essential aspect of EM, since it classifies and describes actions related to all relevant environmental knowledge areas, from product acquisition, design and manufacture, to product service and disposal. On the other hand, use of KM to tackle environmental issues can help companies to better understand what can be done about environmental problems and how to realize the benefits of environmentally responsible actions (Frick, 
Kaiser, \& Wilson, 2004). Most of the literature on environmental knowledge management (EKM) focuses on informational and softer decision-making tools rather than on appropriate understanding of specific environmental knowledge areas and their connection to organizational structure and culture (Heeney \& Murphy, 1999). Environmental knowledge management should combine tools, mechanism, processes, structures, strategies, data, and information with people's experiences and ideas to enable the creation, capture, sharing, acquisition, and use of knowledge (Huang \& Shih, 2009). Consequently, this research employs knowledge management and the product life cycle approach to address individual environmental knowledge areas about ecoefficiency and waste management and their interrelations. There are four relevant challenges for this study based on the literature. The first is incoherence between environmental knowledge about management of raw materials, energy efficiency, and waste (Kaiser \& Fuhrer, 2003). Companies have knowledge gaps in understanding and utilization of product life cycle processes due to the complex relationship between raw materials, energy, and waste. The second challenge is related to an inability to identify and analyze all relevant environmental aspects and impacts within the areas of raw materials, energy, and waste management. Companies need to develop an atomistic approach for every business process in order to gain understanding about the risks, costs and benefits of their actions for the each knowledge area (Ipe, 2003; Kaiser \& Fuhrer, 2003). The third challenge arises from a lack of empowerment of employees, which prevents them from taking relevant environmental actions. Boiral (2002) emphasizes that managers and environmental specialists must visit work sites and discuss with employees in order to identify their knowledge and competencies as well as to encourage them to think, share, and use their environmental knowledge. Companies also need to find solutions to integrate individual knowledge, plans, experience, and goals into organizational structures. The fourth challenge is found in external contacts and knowledge acquisition from stakeholders and suppliers. This challenge is related to the ability of organizations to acquire relevant external knowledge and integrate it appropriately into internal knowledge (Jørgensen, 2006, 2008).

The general aim of this research is to analyze how companies identify relevant eco-efficiency and waste management aspects, their relations and causes, and how they act to address these aspects. Additionally, employing KM and the life cycle approach, this paper sets the following specific objectives:

a) to analyze how companies acquire knowledge on eco-efficiency and waste management internally and externally;

b) to analyze how companies share knowledge on eco-efficiency and waste management internally and externally;

c) to outline the way in which companies use and create knowledge about eco-efficiency and waste management;

d) to analyze knowledge accumulation and retrieval about eco-efficiency and waste management;

This research focuses on the Finnish companies in food and drink sectors. The food and drink industry is the fourth biggest industry in Finland and, at the same time, one of the greatest users of materials and energy. It causes $20-30 \%$ of various environmental impacts, related to intensive farming and agricultural land use, energy inefficiencies in acquisition and production, water consumption, increased packaging and bio-waste, and long transportation distances. This paper addresses the aforementioned energy inefficiencies, waste generation, and the use of natural resources. Furthermore, the paper combines knowledge management and life cycle approaches to analyze business activities (farming and purchasing of raw materials, manufacturing, distributing, and disposing) and their effects on eco-efficiency and waste management. 


\section{Theoretical Background}

Environmental knowledge can be defined as the knowledge that people have about the environment, key relationships involving environmental aspects and impacts, and collective responsibilities for sustainable development (Fryxell \& Lo, 2003). Environmental knowledge in organizations has four forms: declarative, procedural, effectiveness, and social knowledge (Kaiser \& Fuhrer, 2003). Each of these forms of environmental knowledge is related to a KM action. Declarative knowledge means obtaining or acquiring descriptive knowledge or knowing "what" as opposed to knowing "how" about relevant environmental aspects (Dalkir, 2005). Procedural knowledge is knowledge about how to create knowledge, how to make decisions, how to diagnose, and how to prescribe courses of action. Effectiveness knowledge means utilization of appropriate actions based on the benefits and costs of these actions. Social knowledge involves the sharing and acquisition of environmental knowledge internally and externally in order to underpin the previous three knowledge forms. Accordingly, these definitions imply that companies need to manage environmental knowledge in order to make it useful for their business activities. EKM, however, includes two further concepts, namely, the skills and competencies to implement environmental knowledge. Detailed analysis of these concepts is out of the scope of this research, but brief definitions are presented to aid understanding of the paper. Within the context of this research, the most relevant knowledge definition is based on a distinction between data and information. Data is a fact, number, or symbol, whereas information is data with a context to provide answers about "who", "what", "where" and "when" (Bellinger, Castro, \& Mills, 2004). Knowledge is information with a meaning and provides answers to "how" and "why" (Bellinger et al., 2004). Skill usually refers to a level of performance, in the sense of accuracy and speed when performing particular tasks (Winterton, Delemare-Le Deist, \& Stringfellow, 2005). Mansfield (2004) contrasts three different usages of competence: outcomes (vocational standards describing what people need to be able to do in employment), tasks that people do (describing what currently happens), and personal traits or characteristics (describing what people are like).

Table 1 describes in the left-hand column relevant eco-efficiency and waste management knowledge areas and in the right-hand column their actions according to the product life cycle stages. This classification of eco-efficiency and waste management actions on the basis of life cycle perspective provides a systematic overview of these actions that may not be obvious in analyses fo-

Table 1. Eco-efficiency and waste management knowledge actions from the life cycle perspective

\begin{tabular}{|l|l|}
\hline $\begin{array}{l}\text { Knowledge areas in } \\
\text { product life cycle } \\
\text { perspective }\end{array}$ & Actions related to the knowledge area \\
\hline $\begin{array}{l}\text { Sourcing, purchasing } \\
\text { raw materials and } \\
\text { energy }\end{array}$ & $\begin{array}{l}\text { Green suppliers, purchasing materials, sourcing of raw ma- } \\
\text { terials and use of energy. }\end{array}$ \\
\hline $\begin{array}{l}\text { Manufacturing/ } \\
\text { Delivering/Packaging }\end{array}$ & $\begin{array}{l}\text { Eco-design and marketing and eco-efficient manufacturing } \\
\text { processes, transformation of renewable and non-renewable } \\
\text { raw materials and energy into a product. ICT and other } \\
\text { technologies that could improve eco-efficiency. }\end{array}$ \\
\hline $\begin{array}{l}\text { Waste management/ } \\
\text { Recycling }\end{array}$ & $\begin{array}{l}\text { Product recycling, reusing and disposing, and energy re- } \\
\text { quirement and environmental wastes associated to these two } \\
\text { activities. }\end{array}$ \\
\hline
\end{tabular}


cusing on the whole production system. Another benefit of this approach is that the relationships between individual knowledge actions throughout the product life cycle also become evident. In the context of the research, eco-efficiency means reducing the use of energy and raw materials resources while raising the product and service quality, productivity, and market share. For the purpose of the paper, waste management is considered as a set of activities and strategies to reduce/avoid the generation of waste, including re-use, recycling, and recovery. Each environmental knowledge area on raw materials, energy efficiency, and waste management has five forms: individual, internal, external, tacit, and explicit dimensions.

The first three knowledge forms, external, individual, and internal, are covered by Sveiby (1997) (Figure 1). External, individual, and internal structures are not objects, but constructions made by people in their constant interaction. The external structure is related to communication and cooperation with clients, partners, and stakeholders. The internal structure includes connections between teams, departments, and all units within an organization in order to improve learning processes. Individual competencies mean organizational capability to educate new and existing employees (Sveiby, 1997). Figure 1 presents the knowledge strategies based on the interaction or individual application these three structures. Sveiby's classification is relevant for this research since it facilitates analysis of external connections, education and training, and internal environmental management activities and strategies.

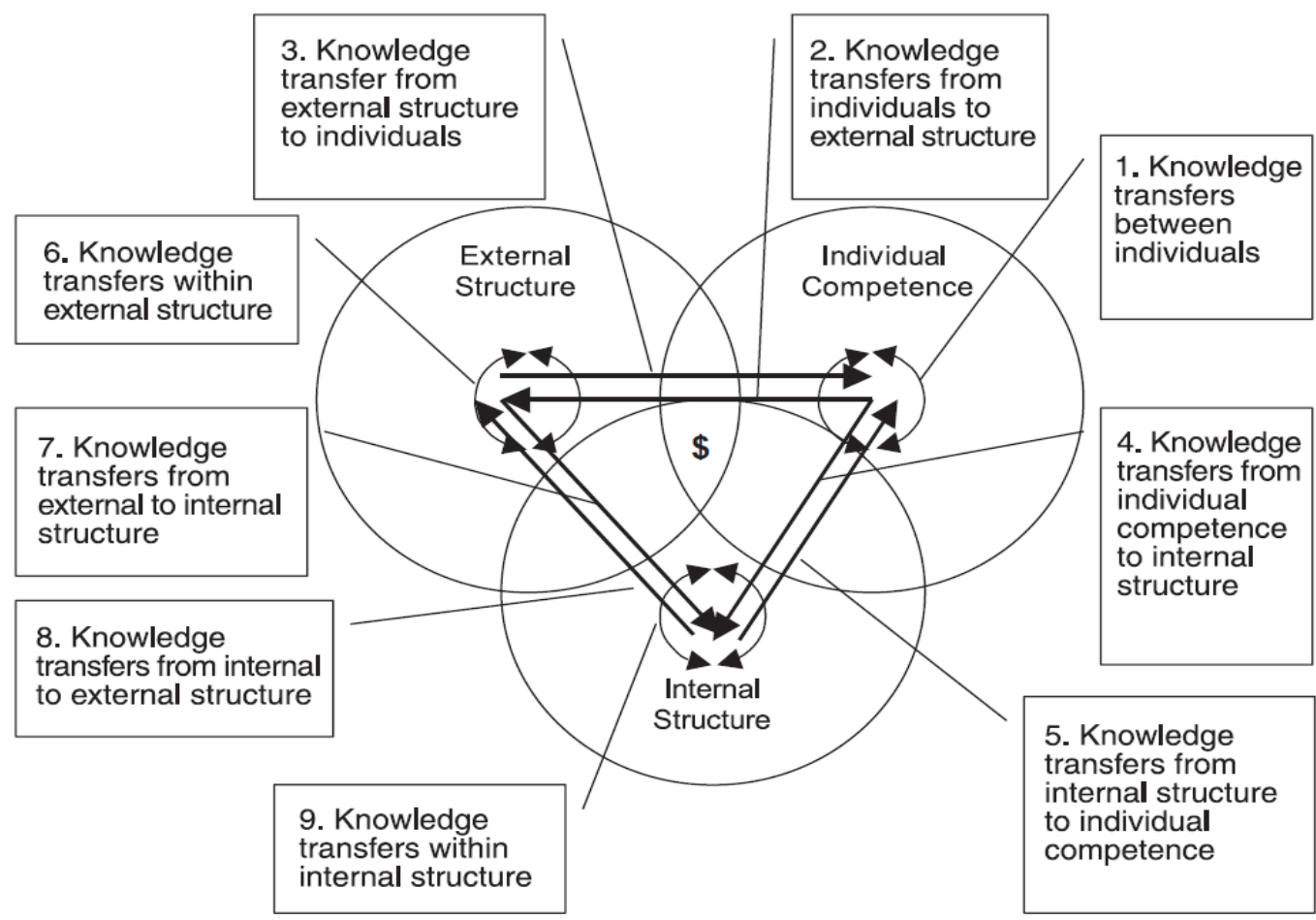

Figure 1. The Ten Knowledge Strategy Issues (Source: Sveiby, 1997)

Takeuchi and Nonaka (2004) described a theory of organizational knowledge creation based on two epistemological dimensions of organizational knowledge conversion; tacit and explicit knowledge. Explicit knowledge is easily codified and transferred from one person to others through dialog, demonstration, or media such as books, drawings, and documents. Tacit knowledge is more difficult to articulate because it often arises out of personal experience, perceptions, insights, and know-how that are implied or indicated but not actually expressed. Tacit knowledge can be identified, improved, and assessed through social methods and activities. There are four 
modes of knowledge conversion: socialization (from tacit to tacit knowledge), externalization (from tacit to explicit knowledge), combination (from explicit to explicit knowledge), and internalization (from explicit to tacit knowledge) (Figure 2). Therefore, Huang and Shih (2009) emphasize the significance of combining tacit and explicit knowledge in organizations and controlling environmental impact via accumulation, utilization, sharing, and creation of environmental knowledge. In the context of this research, the theory of organizational knowledge creation is important because companies use their knowledge resources differently, emphasizing either tacit or explicit knowledge management approaches.

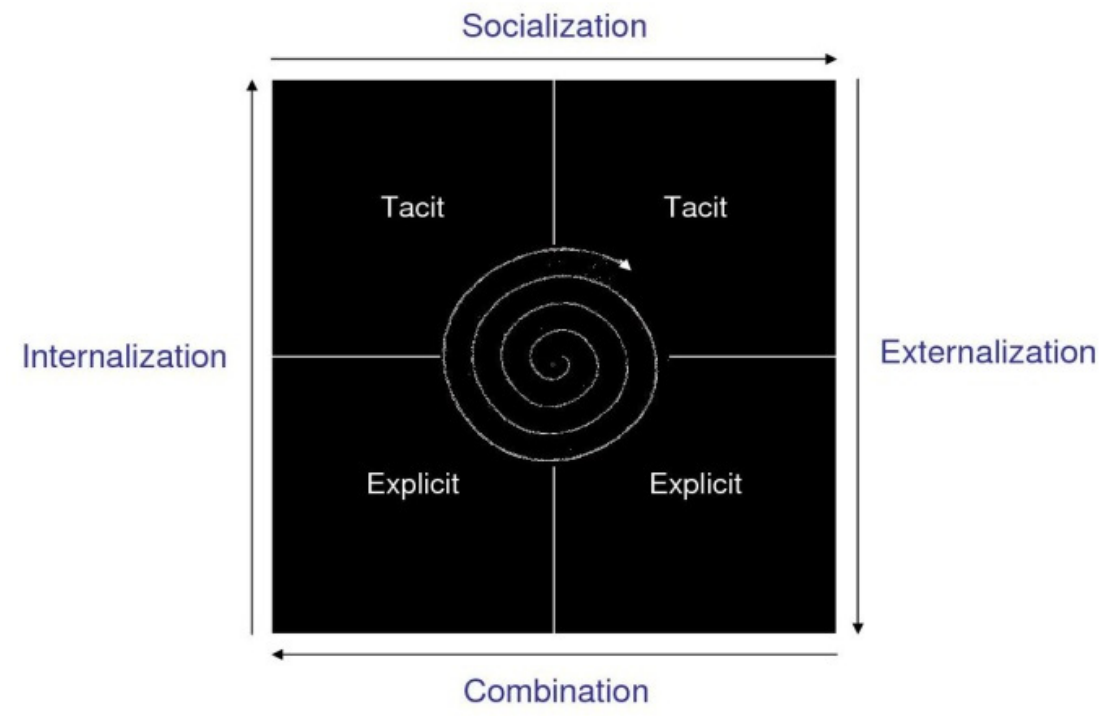

Figure 2. SECI model

(Source: Takeuchi \& Nonaka, 2004)

\section{Methodology}

In this study, the main sources of data and information were interviews (for primary data) and written documents for secondary data (e.g., reports, environmental plans, and websites giving information on the companies). Interviews of key officials and personnel (e.g., CEOs, Environmental Managers, Production Managers, and CSR Managers) were conducted during the period April to June 2012. Prior to the interviews, a discussion guide (Appendix A) was provided in order to facilitate the discussion. Since the nature of the paper is qualitative and descriptive, interviews and/or discussions were considered as the most convenient technique for collection of primary data and information. The secondary data were mainly used for supporting informants' claims about eco-efficiency and waste management indicators, plans, and targets. The request for participation in the research was sent to 42 food and drink companies in the Lahti and Helsinki region. From that number, 11 companies chose to participate, 15 were not able to participate due to the tight business schedule and reorganizational issues, while 16 companies claimed that knowledge on eco-efficiency and waste management was not relevant for them. This was justified by stating that their business processes had not had noticeable effects on the eco-efficiency and waste generation. The conspicuous number of companies that considered the issues of ecoefficiency and waste management irrelevant is itself a very important finding, which will be further analyzed in the results section. The modest response from the companies certainly presents one limitation of the study. However, it was expected in the period of the global economic crisis. 
Table 2 presents the main business areas of the 11 participating companies and the position of the key informants. A total of 14 people were interviewed. As it can be seen from Table 2, the scope of the study is rather wide, involving various sectors of food and drink industry. This approach ipso facto limits the sharpness of the study. Nevertheless, such broadness was necessary due to the scarcity of environmental knowledge management literature and the ambiguity of current environmental knowledge state and phenomena in the Finnish food and drink industry. The first reason for selecting this type of industry is that the investment of Finnish food and drink industry in research and development (2.6\% of production value) is among the highest in Europe (Finnish Food and Drink Industries' Federation, n.d.). The second reason is that about $85 \%$ of all raw materials used in the industry originate from Finland. These two trends provides a good basis for this research since they indicate the needs for more efficient production processes, organized knowledge management processes, and constant improving business operations. Data analysis was done by categorization and thematic coding. The coding was done line-by-line, where each statement from one informant was compared to statements from other informants and then categorized according to their similarities and differences. The next step was comparison of these categories based on the aims of the research, after which observations inside the categories that most match the research topics were selected for further analysis and discussion (Appendix B). The names of companies are coded due to confidentiality agreements.

Table 2. Description of the companies participating in the research

\begin{tabular}{|l|l|l|}
\hline $\begin{array}{c}\text { Company } \\
\text { code }\end{array}$ & \multicolumn{1}{|c|}{ Industries } & \multicolumn{1}{c|}{ Interviewed personnel } \\
\hline A & Bakery & Production manager \\
\hline B & Bakery & Production and quality managers \\
\hline C & Beer and soft drinks & Production and environmental managers \\
\hline D & Malting barley & CEO \\
\hline E & Salads & CEO \\
\hline F & Meat & CEO \\
\hline G & Cheese & Production manager \\
\hline H & Confectionery & CEO \\
\hline I & Yeast & CEO and production manager \\
\hline J & Rape seed oil & CEO \\
\hline $\mathrm{K}$ & Malt, cereal and enzyme extracts & CEO \\
\hline
\end{tabular}

\section{Results}

The first result of the study actually originates from the 16 non-participating companies. The claim of these companies, that eco-efficiency and waste management is not currently relevant for their business, has three implications. The first is that they have lack of environmental knowledge since they cannot recognize the environmental impacts. The second is that they act reactively in addressing environmental impacts, waiting for some significant environmental change in order to intervene. The third implication relates to their lack of awareness or care for the environment. The explanation of such behavior can be found in the traditional business approach of the companies, where environmental and economic values are considered as separated issues.

The other results are divided into subsections based on the relevant EKM processes: acquisition, creation, use, sharing, and retention of environmental knowledge. Each subsection describes how the individual EKM process is applied to knowledge of raw material efficiency, energy efficiency, and waste management. Based on the analysis, it is found that application of environmental knowledge is conjoined with environmental knowledge creation, for which reason the knowledge application is discussed as a part of the knowledge creation process. 


\section{Knowledge Acquisition}

Companies in this study obtain knowledge in the following ways: by testing raw materials, by measuring raw materials, by evaluating energy and waste, and by organizing informal and formal meetings and trainings. The most relevant aspects for all three knowledge areas from the life cycle perspective are quality, yield, price, transportation, and waste handling. Based on the methods in acquiring tacit and explicit knowledge, the companies in the study can be allocated to two groups. The first group measures and tests raw materials while the second group completely relies on specifications and agreements with their suppliers. Of the 11 companies, seven companies (64\%) from the first group conduct measuring and testing of the quality of raw materials and their yield. These companies monitor inputs and outputs of raw materials for every step in the production process per production line. Specifically, company D (malting barley) from this group emphasizes that eco-efficiency can be achieved by reducing the production time and cycles but not reducing their amount. The production depends on the quality and structure of the raw materials. This company acquires knowledge about quality parameters and structure of raw materials such as grain size, viscosity, diastatic power, and the level of various enzymes by testing raw materials and measuring every input and output along production processes. By adopting this approach, the malting barley company can decrease energy consumption by $20 \%$ and completely avoid biowaste. If raw materials are pure, in every batch, production is simplified, and the energy saving is higher and waste reduction greater. On the other hand, for four companies (36\%), from the second group, specifications and certificates are the most important criteria and guarantors of quality. These companies report to suppliers if there is some deviation in the raw materials used in production. Of particular interest in this group is company B (bakery), which claims that all aspects (quality, availability, price, and transportation) of raw materials are the responsibility of the suppliers. In the case of non-compliance, this bakery company acts in accordance with the United Nations Convention on Contracts for the International Sale of Goods (CIGS). A common factor for both groups of companies is constant discussion with suppliers and auditing in order to minimize possible problems. The main difference between these two groups of companies can be ascribed to their attitudes and approaches to environmental and economic risks. The first group $(64 \%)$ aims to eliminate or minimize these risks at the sourcing phase and afterwards improve the efficiency of the whole system by analyzing its constituent parts. The second group (36\%) focuses more on acquiring knowledge about the whole production system rather than knowledge about individual inputs and outputs of production units.

In the monitoring of energy, water, and waste, the companies' approaches differ from those used for raw materials. Five companies, A (bakery), C (beer and soft drinks), D (malting barley), H (confectionary), and $\mathrm{J}$ (rape seed oil) adopt the same atomistic approach to measuring these aspects while the other six companies have either monthly or yearly specifications about water, energy, and waste. The different approach to water, energy, and waste measurement is due to the focus on raw material efficiency as primary knowledge and a lack of competencies, knowledge, and organizational planning for energy efficiency, and waste management. Knowledge about raw materials is primary because the quality, availability, yields, and processing of raw materials has the greatest effect on the economic and business performances of the companies. According to Forsström et al. (2011) improvement in energy efficiency can be made only if a company has an atomistic insight into energy use. In other words, correct measurement of energy should consider all aspects of manufacturing, raw material procurement, and waste management in the life cycle since each subsystem is a life cycle in itself. To address the above-mentioned limitations, these six companies rely on external knowledge acquisition in monitoring and measuring energy, monitoring the equipment, and handling waste.

Transportation is generally outsourced. Companies A (bakery), B (bakery), and C (beer and soft drinks) optimize their routes to reduce the environmental impact of transportation. They gather 
information from their logistics and supply departments to create plans for effective delivery and purchasing movements between suppliers, customers, and their factories. They also cooperate with their competitors, since they use the same trucks (bakery companies A and B) and in that way optimize their number, thus reducing the impact of transportation on energy demand. Similar to this initiative for cooperation, companies A (bakery) and F (meat) plan to sign a contract agreement of buying all raw materials from local farmers that are close to their production sites.

In the companies studied, acquisition of knowledge about measuring, use, and transformation of raw materials and energy is generally a combination of internal and external activities through learning-by-doing and learning from others. Learning from others is mostly developed through internal training or meetings, while learning-by-doing occurs during work activities. Implementation of these two knowledge management approaches is more challenging for the three multiunit companies: A (bakery), B (bakery), and C (beer and soft drinks). Because of their size, these companies strive to balance the level of knowledge, information, and competencies that is essential for utilization of raw materials, use of equipment, and waste prevention between specialists and other employees. To address this challenge, company $\mathrm{C}$ (beer and soft drinks) runs an internal auditing program for all employees and educates new auditors every year as a way to reduce the knowledge gap. Using this tacit knowledge acquisition approach by interviewing and direct communication, company $\mathrm{C}$ can obtain information about individual knowledge, ideas, goals, and plans and can take appropriate actions to empower that knowledge and integrate it into organizational knowledge.

External knowledge acquisition is the most dominant in waste management compared to knowledge of raw material and energy efficiency. All companies in the study have to communicate with their suppliers and customers to optimize supplies and demands and to avoid production, packaging, and other waste streams. Generally, knowledge acquisition pertinent to waste minimization in the participated companies can be described as occurring in three steps:

1. Discussion with customers about estimates of product quantity for about 4 months ahead. Based on that information the companies create production plans and optimize their warehousing.

2. Discussion with suppliers about quantities in order to optimize production batches, and use of raw materials and to satisfy demand.

3. The third step depends on the companies' activities in monitoring waste. Seven companies monitor waste every day, for every product, and use educational programs to educate people and embed that knowledge in daily activities. The other four companies check their guidelines, specifications, and production manuals.

All the participating companies have similar views on knowledge acquisition, since their equipment and technologies mostly depend on consumption of raw materials, and, thus, improvements in energy efficiency and waste management are mostly made from the perspective of raw materials. Based on the observations described above, it is inferred that knowledge acquisition activities are least harnessed for monitoring of energy, waste recycling, transport optimization, and purchasing raw materials. Table 3 presents relevant knowledge acquisition strategies which are above discussed based on the companies' activities. 
Table 3. Environmental knowledge acquisition strategy

\begin{tabular}{|c|c|c|c|}
\hline $\begin{array}{l}\text { Knowledge } \\
\text { area }\end{array}$ & Knowledge acquisition strategy & $\begin{array}{l}\text { No. of companies that } \\
\text { apply the strategy }\end{array}$ & Percentage \\
\hline \multirow{3}{*}{$\begin{array}{l}\text { Raw materials } \\
\text { efficiency }\end{array}$} & Trainings and meetings & 11 & 100 \\
\hline & Daily measuring and testing & 7 & 64 \\
\hline & Follow specifications & 4 & 36 \\
\hline \multirow{3}{*}{$\begin{array}{l}\text { Energy } \\
\text { efficiency }\end{array}$} & Daily measuring & 5 & 45 \\
\hline & Monthly and yearly measuring & 6 & 55 \\
\hline & Optimizing transportation routes & 3 & 27 \\
\hline \multirow{3}{*}{$\begin{array}{l}\text { Waste } \\
\text { management }\end{array}$} & Internal recycling and reusing & 5 & 45 \\
\hline & External recycling and reusing & 6 & 55 \\
\hline & Measuring daily & 7 & 64 \\
\hline
\end{tabular}

\section{Knowledge Creation}

All companies in the study create new knowledge in three ways: internally, externally, and by combining internal and external knowledge. Knowledge creation for energy efficiency is different from that of knowledge creation for raw materials and waste management. Energy efficiency knowledge requires the integration of external structures, while raw material and waste management knowledge creation are mostly internal issues. Creation of knowledge about raw material, energy, and waste management is rooted in the acquisition, sharing, and application of these types of knowledge. According to the analysis, the first step in knowledge creation is obtaining the knowledge internally and/or externally in a tacit way by training or other social activities. The second step is further processing of external knowledge through meetings and other forms of knowledge dissemination. The third step includes testing or applying knowledge in production. During this third stage, individual and team competencies become essential, such as how fast employees are doing their tasks and how much their competencies are equal. The final step is internal analysis of business activities and processes. This step embraces all three previous steps. The difference among the environmental knowledge areas in this procedure is that knowledge of energy efficiency and waste management is not equally integrated in the companies' individual structures.

Improvements are mostly focused on producing different ingredients which can be used faster to reduce production time. Accordingly, tacit knowledge is embedded in all the above-mentioned knowledge creation steps. A tacit knowledge management approach is dominant in the companies due to craftsman skills, a need for social interaction since most employees do not have computers, and face-to-face meetings or training sessions with customers and suppliers. The only way to manage employees' knowledge is to directly observe or discuss with them how they maintain the equipment, how they prevent waste, and how they use raw materials and energy. For example, company $\mathrm{H}$ (confectionery) is very aware of the nature of their business, and that is why its practice is to organize daily visits and discussions of managers and the CEO with employees on the worksite in order to improve interpersonal and professional relationships.

Generally, innovations in the companies depend on resources, investments, and external support. In the context of this research, innovation is not only considered as new products on the market but as any improvement in processes or business procedures that can increase environmental and economic performance. A tacit knowledge management approach is successful only if managers develop a strategy that affects employees and customers positively. For example, company $\mathrm{G}$ (cheese industry) presented the usefulness of direct communication and rewards that encourage 
employees to use their knowledge. As a result of this approach, company $\mathrm{G}$ created a new reusing method to save 10 meters of shrinking film in a deep drain machine for cheese shrinking. Company $\mathrm{D}$ (malting barley industry) combines idea banks for capturing and promoting innovative thinking with the usual activities of its research and development department.

Another approach to managing eco-efficiency and waste management is the use of lean management. Companies A (bakery) and C (beer and soft drinks) rely on lean management, which considers systematical and atomistic procedure in observing and utilizing production processes by measuring and combining data with people's knowledge and experience. According to the informant from company A, lean management helps them to keep waste at 3\% compared to $7 \%$ six years ago. This level of 3\% for company A has been unchanged for the last two years. At this point, it is important to emphasize that lean management brings results only if it includes all knowledge flows between all units in the companies. Lean management for itself, without the full integration of knowledge management processes, can improve performances only to a certain level. If a production system becomes more dynamic and massive then more attention is needed to knowledge flows (Nordin, Md Deros, Abdul Wahab, \& Rahman, 2012). This fact could be an explanation why company A struggles in the last two years in reducing their waste, because they are lacking to identify all knowledge flows (Dombrowski, Mielke, \& Engel, 2012). Informant from company A specified that if they could constantly keep the waste under 3\% that would save the costs for a hundred thousands of dollars yearly.

Most internal innovations come from knowledge about raw materials. The companies improve their overall efficiency by reducing the time of utilization of raw materials, combining and testing various ingredients that are simpler for production, and improving employees' competencies in transforming raw materials and energy. The best illustration of the different knowledge creation approaches for energy efficiency and raw material knowledge comes from company $\mathrm{F}$ (meat industry). Four years ago, company $\mathrm{F}$ implemented an extensive program to minimize electricity consumption, for which they used an external consultancy. Nowadays, this company has no activities specifically aimed at water or electricity savings. Company $F$ has been considering new projects for energy savings and renewable energy, but they have to consider the costs and benefits of such a project. On the other hand, for raw materials utilization, there is a very systematic approach for measuring and testing raw materials and implementing research activities in cooperation with other companies developing organic meat and natural additives.

The companies do not combine tacit and explicit knowledge for raw materials, energy efficiency, and waste in the same way. Tacit and explicit knowledge creation for all the three knowledge areas are equally developed for $64 \%$ participating companies which combine social activities such as learning by doing and measuring. For energy efficiency and waste management, tacit knowledge creation is dominant in $36 \%$ of the companies mostly through their external structure.

Based on the previous discussion and the research analysis, Table 4 presents relevant knowledge creation strategies about raw materials, energy and waste in the companies. 
Table 4. Environmental knowledge creation strategies

\begin{tabular}{|c|c|c|c|}
\hline $\begin{array}{l}\text { Knowledge } \\
\text { area }\end{array}$ & Knowledge creation strategy & $\begin{array}{l}\text { No. of companies that } \\
\text { apply the strategy }\end{array}$ & Percentage \\
\hline \multirow[b]{3}{*}{$\begin{array}{l}\text { Raw materials } \\
\text { efficiency }\end{array}$} & Lean thinking & 2 & 18 \\
\hline & Learning by doing & 5 & 45 \\
\hline & $\begin{array}{l}\text { Intranet, document and speci- } \\
\text { fication sharing and acquisition }\end{array}$ & 4 & 36 \\
\hline \multirow[b]{3}{*}{$\begin{array}{l}\text { Energy } \\
\text { efficiency }\end{array}$} & Lean thinking & 2 & 18 \\
\hline & Measuring and testing & 5 & 45 \\
\hline & $\begin{array}{l}\text { External acquisition and utili- } \\
\text { zation }\end{array}$ & 4 & 36 \\
\hline \multirow{3}{*}{$\begin{array}{l}\text { Waste } \\
\text { management }\end{array}$} & Lean thinking & 2 & 18 \\
\hline & $\begin{array}{l}\text { External acquisition and utili- } \\
\text { zation }\end{array}$ & 4 & 36 \\
\hline & $\begin{array}{l}\text { Internal and external obtaining, } \\
\text { sharing and application }\end{array}$ & 5 & 45 \\
\hline
\end{tabular}

\section{Knowledge Sharing}

Knowledge sharing activities of the participating companies are in the form of meetings, social activities, and apprenticeships, internally and externally (Table 5). These activities are implemented differently in multiunit and single unit companies. The three multiunit companies, namely, companies A (bakery), B (bakery), and C (beer and soft drinks), strive to continuously disseminate knowledge and information about raw material, energy, and waste management throughout business areas such as production, sales, marketing, supply, and logistics. Production operators and environmental managers in the companies have weekly or monthly meetings, after which they disseminate relevant information to other employees at the worksite. These three companies do not have officially established communities of practices, collections of people who engage on an ongoing basis in some common endeavor (Eckert, 2006), although they share knowledge based on their common tasks or interests in specific areas of knowledge. Despite their efforts, there is a gap in transferring knowledge within the companies, even among different business areas that could be interested in the same type of knowledge. Data and information are not available to everyone who needs them; a discrepancy that is expressed most in sharing information about suppliers, transportation, energy use, and the purchase of raw materials. For example, despite all departments in company $\mathrm{C}$ (beer and soft drinks) using the same servers and resources, they do not inform other departments or individuals about their updates and the locations of these updates.

Internal knowledge sharing in the single unit companies is mostly by face-to-face communication. All employees are easily available and direct communication between managers or CEOs and employees is much more frequent. These companies can easily organize meetings or visit production sites. Additionally, the single unit companies have official and some smaller group meetings once a week. It was noted that these companies better leverage and share their tacit knowledge compared to multiunit companies due to people's vicinity and availability. Accordingly, Table 5 presents which knowledge sharing methods for raw materials, energy and waste management are the most relevant in the eleven companies. 
Table 5. Environmental knowledge sharing strategy

\begin{tabular}{|c|c|c|c|}
\hline $\begin{array}{l}\text { Knowledge } \\
\text { area }\end{array}$ & Knowledge sharing strategy & $\begin{array}{l}\text { No. of companies that } \\
\text { apply the strategy }\end{array}$ & Percentage \\
\hline \multirow{2}{*}{$\begin{array}{l}\text { Raw materials } \\
\text { Efficiency }\end{array}$} & $\begin{array}{l}\text { Internal and external meetings, } \\
\text { apprenticeship and consultancy }\end{array}$ & 11 & 100 \\
\hline & $\begin{array}{l}\text { Documents and specifications } \\
\text { by intranet }\end{array}$ & 4 & 36 \\
\hline \multirow{2}{*}{$\begin{array}{l}\text { Energy effi- } \\
\text { ciency }\end{array}$} & $\begin{array}{l}\text { Internal meetings and document } \\
\text { sharing approaches }\end{array}$ & 5 & 45 \\
\hline & $\begin{array}{l}\text { External meetings and coopera- } \\
\text { tion }\end{array}$ & 6 & 55 \\
\hline \multirow{2}{*}{$\begin{array}{l}\text { Waste man- } \\
\text { agement }\end{array}$} & $\begin{array}{l}\text { Internal meetings and document } \\
\text { sharing approaches }\end{array}$ & 7 & 63 \\
\hline & $\begin{array}{l}\text { External meetings and consul- } \\
\text { tancy }\end{array}$ & 4 & 36 \\
\hline
\end{tabular}

Generally, all companies in the study strive for a more uniform transfer of codified and noncodified knowledge and competencies. The multiunit companies and the single unit companies need to strategically establish what kind of sharing techniques are most suitable for their organization and promote these techniques among the employees. Consequently, the main challenges in knowledge sharing are awareness of environmental knowledge sharing and appropriate integration of human and technological resources in monitoring and identifying knowledge flows.

\section{Retaining the Knowledge}

Retention of tacit and explicit environmental knowledge about eco-efficiency and waste management occurs at various levels. A prerequisite for successful capturing and retention of knowledge is existence of organizational memory. Managing organizational memory increases new product innovativeness and enhances new product success rates (Chang \& Ho, 2008). Moorman and Minner (1997) proposed three forms of organizational memory that can be identified in companies. The first is found in organizational beliefs, knowledge, values, norms, and mutual trust. Organizational memory related to this form is general, explicit, and articulated knowledge. In the case of the companies in this study, knowledge about safety, quality, environmental plans, reports, and agreements belongs to this form of organizational memory. This type of organizational memory was expressed in eight companies. However, it should be noted here that, even though the other three companies, E (salads), F (meat), G (cheese), do not have activities relating to the retention of eco-efficiency reports and plans (due to the lack of resources), this does not mean they do not think about eco-efficiency and its improvement. As it can be seen in the previous sections, these companies have some significant achievements.

The second form of organizational memory is related to learning from experience, observing, and doing things that become encoded in formal and informal behavioral routines, procedures, and scripts. This form of knowledge is the most important and at the same time the most difficult to codify. Dalkir (2005) notes that an interviewing technique is the most effective method for capturing tacit knowledge since the approach can be used not only for investigating individual skills but also emotions and attitudes, as in the case of company $\mathrm{C}$ (beer and soft drinks). In the context of this research, company activities such as identification of best practices, support for idea banks, organization of daily meetings, and brainstorming sessions represent this form of knowl- 
edge. This second form of organizational memory can be recognized in six companies in the study.

The third form of organizational memory is found in an organization's physical artifacts, i.e., knowledge is externalized into documents, reports, intranets, and information systems. This form of organizational memory is noted in the three companies: A (bakery), B (bakery), and C (beer and soft drinks). For example, company B (bakery) especially prefers this form of organizational memory, emphasizing availability and sharing opportunities for their policies, documents and plans. However, successful knowledge retention cannot be guaranteed since the companies need to apply a suitable strategy or method to manage their organizational memory. Company A (bakery) captures information from their customers with SAP business and management solutions and uses interviews to capture individual tacit knowledge. The problem with this approach is that the information about customers and results of interviews are not available to majority of employees due to limitations in computer access and lack of communication when updating and storing data. Company A does not employ structured methods or strategies to describe, visualize, or make more widely available knowledge, for example, in a knowledge base, map, or taxonomy. On the other hand, company $\mathrm{F}$ (meat industry) claims that all its employees have equally developed skills, but this company does not use any method to capture or identify those skills and actions. Even though company F organizes official meetings with all its suppliers four times a year, as part of the benchmarking processes, it does not have activities to retain the knowledge, information, and data gained from the meetings to combine them with internal tacit practices. Environmental knowledge accumulation is not systematically utilized in the companies studied due to its requirement for additional investment in informational structures and its demands on employees' time.

Table 6 presents the companies' strategies for tacit and explicit environmental knowledge accumulation according to the type of organizational memory they use for knowledge on raw materials, energy and waste management.

Table 6. Environmental knowledge retention strategy

\begin{tabular}{|c|c|c|c|}
\hline $\begin{array}{l}\text { Knowledge } \\
\text { area }\end{array}$ & $\begin{array}{l}\text { Knowledge retention } \\
\text { strategy }\end{array}$ & $\begin{array}{l}\text { No. of companies that } \\
\text { apply the strategy }\end{array}$ & Percentage \\
\hline \multirow{4}{*}{$\begin{array}{l}\text { Raw materials, } \\
\text { energy effi- } \\
\text { ciency and } \\
\text { waste manage- } \\
\text { ment }\end{array}$} & $\begin{array}{l}\text { Documents about safety, } \\
\text { quality and agreements }\end{array}$ & 11 & 100 \\
\hline & $\begin{array}{l}\text { Without eco- efficiency } \\
\text { reports }\end{array}$ & 3 & 27 \\
\hline & $\begin{array}{l}\text { Interviews, idea banks, } \\
\text { brainstorming }\end{array}$ & 6 & 55 \\
\hline & SAP, intranet & 3 & 27 \\
\hline
\end{tabular}

\section{Discussion}

Based on the results of the study, the general observation is that the 11 participating companies are very aware of the environmental knowledge management, but demonstrate different levels of understanding and applying it. Even though none of the companies has developed a deliberate policy or strategy of KM, their activities, culture and structure unintentionally satisfy the basis of KM. This observation is similar with the observation of Massa and Testa (2009) on two Italian food companies. However, what is different from their study is the analysis and presentation of the knowledge management processes. Massa and Testa prioritized individual knowledge management processes, relating to the focus of these two companies (marketing and technology knowledge domains). This paper, on the other hand, points out to the equal importance of all 
knowledge management processes (acquisition, creation, application, sharing, and retention) regardless of the company's focus. The study further demonstrates that implementation of KM processes on eco-efficiency in the Finnish food and drink industry has a great potential, but it is nevertheless conducted slowly. This finding is in accordance with Hoffrén and Apajalahti's (2009) claim that breakthrough of environmental knowledge and full awareness of eco-efficiency is yet to come. However, our paper questions their method, consisting of the statistical analysis on environmental reporting of companies about eco-efficiency thinking and activities. Namely, their result, that only $10 \%$ of 76 companies adopted eco-efficiency thinking, and practice, was based on determining whether the companies had environmental reports or not and how well companies established the connection between the environmental and economic values. This study, nevertheless, shows that in the case when a company does not have captured explicit environmental knowledge (reports, requirements, or policy), it could still apply eco-efficiency thinking and activities. Support for such a claim lies in companies E (salads), F (meat), and G (cheese).

The phenomenon of favoring the knowledge on raw materials compared to the knowledge on energy efficiency, which was outlined in the results, is also present in the Canadian food and beverage industry. Maxime, Marcotte, and Arcand (2006) argue that the Canadian food and beverage industry pays little attention to the energy consumption of processes, since $80 \%$ of manufacturing costs are related to the processing of raw materials. They emphasize that there is enormous potential for energy savings (between 10-50\%) in processes related to heating (drying, sterilization, pasteurization, and evaporation) and cooling (freezing, refrigeration). Informants from this study identified these processes as the most critical too, and they explained how their companies had been trying to address these issues. Company $G$ (cheese) is improving insulation system of their rooms and boilers where cheese needs to be cooled and heated, and it is investing in smart technologies that automatically regulate temperature in rooms and boilers. This company also educates employees how to use their equipment during the work in order to save electrical energy. On the other side, for company F (salads) is not at this moment technologically able to reduce energy use in cooling and heating or to switch their energy power to the renewable, because the company needs a lot of steam for pasteurization which can be provided only by oil, but they use this heat surplus to warm up other rooms.

Concerning energy efficiency, Martinez (2010) claimed that economics, technical abilities, and fuel substitution have played important factors because increases in economic growth and technology improvement increase the industrial ability to improve energy efficiency. This study supports this claim, but it also expands it by highlighting that the knowledge on energy and materials efficiency of employees should also be considered in evaluation of economic and environmental values. Our research further shows that implementation of knowledge management processes on eco-efficiency and waste management certainly raises companies' value, as Sinkin, Wright, and Burnett (2008) have also shown.

Pagan and Praisad (2007) have demonstrated in their study that food companies in different sectors could profit from eco-efficiency mostly by reducing the waste and by minimizing energy and water consumption. They specified that important drivers in achieving these changes are collaborative approach between the industrial companies, government, and external consultancy, especially in the case of companies that are not totally convinced in the benefits of eco-efficiency. This paper has a similar finding, and it also explains why external collaboration is more dominant in transportation, energy use, and waste management than in the internal and individual structures.

Peacock et al. (2011) have suggested that information about functional unit, system boundaries, allocation of environmental aspects, and impact categories about food and drink products along the life cycle could be harmonized. Nevertheless, they have also identified some challenge relating to the environmental aspects complexity and their interconnection. This study demonstrates 
that these challenges could be addressed through the identification and understanding of environmental knowledge aspects from the life cycle perspective and their integration in the knowledge management processes.

All our findings suggest that environmental knowledge management on eco-efficiency in food and drink industries from the life cycle perspective certainly deserves more attention in the future.

\section{Conclusion and Recommendations}

This paper analyzed how 11 Finnish companies in the food and drink sector utilize environmental knowledge management processes on raw materials, energy efficiency, and waste management from the product life cycle perspective. The majority of researches were using a quantitative approach combined with software solutions in the analysis of eco-efficiency and waste management. This research has favored a qualitative one, focusing on the organizational and technological capabilities of companies to manage the environmental knowledge from the life cycle perspective. Eco-efficiency and waste management indicators and models can identify a level of some phenomena, but issues such as how to address these phenomena and what are their causes can be achieved only through systematical analysis of knowledge areas related to eco-efficiency and waste management. Systematical analysis in this case was achieved by combining knowledge management and the life cycle perspective. This paper argues that the main focus of companies should be on awareness and understanding of eco-efficiency and waste management tacit and explicit knowledge and its occurrence at individual, internal, and external level of a company.

The analysis has four major findings. The first is that the companies prefer a tacit knowledge management approach for their business activities. All the companies favor a tacit KM approach due to central importance of craftsmanship and practical skills in the production processes. The second finding is that knowledge on raw materials is the most developed knowledge area and the major driver of innovations in the companies. Knowledge on raw materials is the priority knowledge since their quality, yield, and availability directly affect business goals and customer satisfaction. Individual, internal, and external structures are leveraged for this knowledge type, while the external structure is the most developed for energy and waste knowledge areas. Innovations in the companies are mainly made from the perspective of raw materials, which means that any improvement in raw materials utilization could lead to an improvement in energy efficiency and waste management, but not vice versa. Thirdly, it is concluded that a lack of integration of KM and the life cycle approach is common. An atomistic and holistic business approaches are the major indicators of the companies' ability to implement and understand the benefits of KM and the life cycle perspective. The greatest barriers to systematic KM and product life cycle implementation are costs, risks on investment, and undefined organizational policies and strategies. The fourth conclusion relates to the knowledge sharing and retention gap. The knowledge sharing gap is the greatest in multiunit companies since they cannot disseminate completely knowledge and skills of expert or experienced people to other employees and they do not have a strategy to make all relevant information available to everyone who needs it. Knowledge capture is the least developed process in the companies mostly because of the lack of awareness and importance of explicit knowledge.

The limitations of the research are related to its wide scope and the modest number of participating companies. These limitations could be overcome in the future by focusing on a specific food and drink sector in the long-term period.

Our paper has three recommendations based on the findings. The first is that knowledge management approach, combined with life cycle approach, clarifies interrelations between ecoefficiency and waste management knowledge aspects, as well as their relations to a company's structure. The second is that KM processes for every aspect are interconnected and that the full 
potential of KM could be achieved only with equal attention to the each process. The third recommendation is that companies certainly should invest more in environmental knowledge management in accordance with its positive impact on their business. Investing in technology and people to enhance and to leverage tacit, explicit, external, internal, and individual components is especially important for food and drink industry, due to their craftsman nature and manufacturing tradition.

\section{References}

Boiral, O. (2002). Tacit knowledge and environment management. Long Range Planning, 35(3), 291-317.

Bellinger, G., Castro, D., \& Mills, A. (2004). Data, information, knowledge, and wisdom. Retrieved October 20, 2000, from http://courseweb.lis.illinois.edu/ katewill/spring2011-

502/502\%20and $\% 20$ other $\% 20$ readings/bellinger $\% 20$ on $\% 20$ ackoff $\% 20$ data $\% 20$ info $\% 20$ know $\% 20$ wis dom.pdf

Chang, D. R., \& Cho, H. (2008). Organizational memory influences new product success. Journal of Business Research, 61(1), 13-23.

Dalkir, K. (2005). Knowledge management in theory and practice. Oxford, UK: Elsevier ButterworthHeinemann.

Dombrowski, U., Mielke, T., \& Engel, C. (2012). Knowledge management in lean production system. 45th The International Academy for Production Engineering (CIRP), Conference on Manufacturing Systems. Retrieved March 24, 2013, from http://www.sciencedirect.com/science/article/pii/S2212827112002478

Eckert, P. (2006). Communities of practices. Retrieved March 12, 2013, from http://www.stanford.edu/ eckert/PDF/eckert2006.pdf.

Finnish Food and Drink Industries' Federation. (n.d.). Food and drink industries. Retrieved February 12, 2102, from http://www.etl.fi/www/en/

Forsström, J., Lahti, P., Pursiheimo, E., Rämä, M., Shemeikka, J., Sipilä, K., ... Wahlgren, I. (2011). Measuring energy efficiency: Indicators and potentials in buildings, communities and energy systems. Retrieved May 23, 2012, from http://www.vtt.fi/inf/pdf/tiedotteet/2011/T2581.pdf

Frick, J., Kaiser, F. G., \& Wilson, M. (2004). Environmental knowledge and conservation behavior: Exploring prevalence and structure in a representative sample. Personality and Individual Differences, $37(8), 1597-1613$.

Fryxel, G., \& Lo, C. W. H. (2003). The influence of environmental knowledge and values on managerial behaviors on behalf of the environment: An empirical examination of managers in China. Jornal of Business Ethics, 46(1), 45-69.

Heeney, D., \& Murphy, L. (1999). From waste management to knowledge management. Retrieved March 16, 2012, from http://indeco.com/www.nsf/Ideas/wm $2 \mathrm{~km}$.

Hoffrén, J., \& Apajalahti, E. L. (2009). Emergency eco-efficiency paradigm in corporate environmental management. Sustainable Development, 17, 233-243.

Huang, P-S., \& Shih, L-H. (2009). Effective environmental management through environmental knowledge management. International Journal of Environment Science and Technology, 6(1), 35-50.

Ipe, M. (2003). Knowledge sharing in organizations: A conceptual framework. Human Resource Development Review, 2(4), 337-359.

Jørgensen, T. H. (2006). Considerations about ISO 14001, and suggestions for the next revision. Retrieved October 9, 2012, from http://vbn.aau.dk/files/3314943/THJ_ISDR_2006.pdf

Jørgensen, T. H. (2008). Towards more sustainable management systems: Through life cycle management and integration. Journal of Cleaner Production, 16(10), 1071-1080. 
Kaiser, F., \& Fuhrer, U. (2003). Ecological behavior's dependency on different forms of knowledge. Applied Psychology: An International Review, 52(4), 598-613.

Mansfield, B. (2004). Competence in transition. Journal of European Industrial Training, 28(2/3/4), 296309.

Martinez, C., I., P. (2010). Analysis of energy efficiency development in the German and Colombian food industries. International Journal of Energy Sector, 4(1), 113-136.

Massa, S., \& Testa, S. (2009). A knowledge management approach to organizational competitive advantage: Evidence from the food sector. European Management Journal, 27, 129-141.

Maxime, D., Marcotte, M., \& Arcand, Y. (2006). Development of eco-efficiency indicators for the Canadian food and beverage industry. Journal of Cleaner Production, 14, 638-648.

Moorman, C., \& Miner, S. A. (1997). The impact of organizational memory on new product performance and creativity. Journal of Marketing Research, 34(1), 91-106.

Nordin, N., Md Deros, B., Abdul Wahab, D., \& Rahman, A., M., N. (2012). A framework for organizational change management in lean manufacturing implementation. International Journal of Services and Operations Management. 12(1), 101-117.

Pagan, B., \& Prasad, P. (2007). The Queensland food eco-efficiency project: Risk and improving competitiveness. Journal of Cleaner Production, 15, 764-771.

Peacock, N., De Camillis, C., Pennington, D., Aichinger, H., Parenti, A., Rennaud, J-P....Ziegler, F. (2011). Toward a harmonised framework methodology for the environmental assessment of food and drink products. The International Journal of Life Cycle Assessment, 16(3), 189-197.

Takeuchi, H., \& Nonaka, I. (2004). Hitotsubashi on knowledge management. John Wiley and Sons.

Sinkin, C., Wright, J. C., \& Burnett D. R. (2008). Eco-efficiency and firm value. Journal of Accounting and Public Policy, 27, 167-176.

Svieby, K. E. (1997). The new organizational wealth: Managing \& measuring knowledge-based assets. San Francisco: Berrett-Koehler Publishers.

Winterton, J., Delemare-Le Deist, F., \& Stringfellow, E. (2005). Typology of knowledge, skills and competencies: Clarification of the concept and prototype. Retrieved October 19, 2012 from www.cedefop.europa.eu/en/Files/3048_EN.PDF 


\section{Appendix A \\ DISCUSSION GUIDE}

\section{Raw materials efficiency}

- main raw materials and their sources

- supplying of raw materials

- relevant environmental aspects and impacts about raw materials and suppliers

- efficiency measures/indicators

- problems of inefficiency or the most critical factors

- improvement plan to attain eco-efficiency in raw materials and supplying

- knowledge management processes for this type of knowledge

\section{Energy efficiency}

- types of used energy (water, gas, oil, electricity, diesel)

- sources/supplies of energy

- relevant environmental aspects for energy supplying

- relevant environmental impacts in energy use (in the acquisition, transport and manufacturing)

- efficiency measures/indicators

- problems of inefficiencies

- improvement plans

- knowledge management processes for this type of knowledge

\section{Waste management and recycling}

- types of all kinds of waste and their share for each stream (e.g. paper, carton, wood, metal, aluminum, plastic, glass, waste water, etc.)

- recycling and reusing the packaging and manufacturing waste (e.g. what are recycled and reused?)

- factors affecting waste generation (machines, human factor or other)

- costs and benefits of waste management (e. g. selling and reusing the co-products or byproducts)

- problems in waste management/recycling

- improvement plans

- knowledge management processes for this type of knowledge 


\section{Appendix B}

\begin{tabular}{|l|l|}
\hline Raw materials categories & Observations \\
\hline Testing raw materials & $\begin{array}{l}\text { 1. Some companies have standards for raw materials use, } \\
\text { but also test the content for every batch } \\
\text { 2. The other companies only require that suppliers follow } \\
\text { their specifications }\end{array}$ \\
\hline $\begin{array}{l}\text { Sharing knowledge about raw } \\
\text { materials internally }\end{array}$ & $\begin{array}{l}\text { 1. Meetings on the different levels daily or weekly } \\
\text { 2. Intranet }\end{array}$ \\
\hline $\begin{array}{l}\text { Sharing the knowledge about } \\
\text { raw materials externally }\end{array}$ & $\begin{array}{l}\text { 1. Meetings, benchmarking } \\
\text { 2. Daily cooperation }\end{array}$ \\
\hline $\begin{array}{l}\text { Creating the knowledge about } \\
\text { raw materials }\end{array}$ & $\begin{array}{l}\text { The four step procedure } \\
\text { 1. Obtaining the tacit knowledge internally and externally }\end{array}$ \\
$\begin{array}{l}\text { 2. Processing of the external knowledge } \\
\text { 3. Applying the knowledge }\end{array}$ \\
\hline Trainings and education & Internally learning from others and by observation \\
\hline $\begin{array}{l}\text { Activities for optimization of } \\
\text { transportation }\end{array}$ & $\begin{array}{l}\text { 1. Cooperating with competitors, optimizing distance trav- } \\
\text { elled, customers' demands and supplies }\end{array}$ \\
\hline $\begin{array}{l}\text { Activities for raw materials ef- } \\
\text { ficiency }\end{array}$ & $\begin{array}{l}\text { 1. Measuring, cooperation with suppliers, other companies } \\
\text { and clients, projects }\end{array}$ \\
\hline Relevant factors & Yield, quality, quantity, transportation, price \\
\hline Measuring raw materials & 1. Daily 2. Monthly 3. Yearly \\
\hline Knowledge retention & Reports, idea banks, SAP system, intranet, interviews \\
\hline $\begin{array}{l}\text { Obtaining knowledge about raw } \\
\text { materials }\end{array}$ & $\begin{array}{l}\text { 1. Testing raw materials, measuring raw materials, energy } \\
\text { and waste, } \\
\text { 2. Organizing informal and formal meetings and trainings }\end{array}$ \\
\hline
\end{tabular}

\begin{tabular}{|l|l|}
\hline $\begin{array}{l}\text { Energy efficiency and renewable } \\
\text { energy categories }\end{array}$ & Observations \\
\hline The most critical processes & $\begin{array}{l}\text { Cooling, reusing hot air, testing, pasteurization, germi- } \\
\text { nation, fermentation }\end{array}$ \\
\hline Relevant energy efficiency aspects & $\begin{array}{l}\text { Quality of raw materials, energy pollution, price and } \\
\text { savings }\end{array}$ \\
\hline $\begin{array}{l}\text { Obtaining knowledge about energy } \\
\text { efficiency }\end{array}$ & $\begin{array}{l}\text { Measuring, organizing informal and formal meetings } \\
\text { and training, internally and externally }\end{array}$ \\
\hline Water efficiency & Measuring, testing, reusing or no activities \\
\hline $\begin{array}{l}\text { Activities improving energy effi- } \\
\text { ciency }\end{array}$ & $\begin{array}{l}\text { Optimizing critical processes, educating people, in- } \\
\text { vestment in technologies and equipment, projects with } \\
\text { partners }\end{array}$ \\
\hline Investments & Renewable energy, education, technology \\
\hline Measurement of energy efficiency & 1. Daily 2. Monthly \\
\hline Renewable energy use & $\begin{array}{l}\text { 1. All processes based on renewable energy } \\
\text { 2. It is not possible to use renewable energy } \\
\text { 3. It is expensive }\end{array}$ \\
\hline
\end{tabular}




\begin{tabular}{|l|l|}
\hline Waste management categories & Observations \\
\hline Measuring waste & 1. Daily 2. Monthly 3. Yearly \\
\hline Recycle/Reuse & $\begin{array}{l}\text { 1. Lean management } \\
\text { 2. Partially } \\
\text { 3. No activities }\end{array}$ \\
\hline Costs and benefits & $\begin{array}{l}\text { Costs of waste management are higher than its benefits, } \\
\text { since the most of the waste is charged for processing by } \\
\text { waste management companies and no returning packag- } \\
\text { ing material from customers }\end{array}$ \\
\hline Waste management activities & $\begin{array}{l}\text { Recycling waste water, reusing water, reusing raw mate- } \\
\text { rials, optimization of warehouses, lean management, } \\
\text { recycling some parts of packaging materials, coopera- } \\
\text { tion with producers of packaging materials }\end{array}$ \\
\hline $\begin{array}{l}\text { Factors contributing to waste gen- } \\
\text { eration }\end{array}$ & $\begin{array}{l}\text { Quality of raw and packaging materials, competencies, } \\
\text { equipment, great variety in packaging materials }\end{array}$ \\
\hline $\begin{array}{l}\text { Investments and addressing prob- } \\
\text { lems }\end{array}$ & $\begin{array}{l}\text { Education, lean processes, eco-design, machines and } \\
\text { technologies for recycling }\end{array}$ \\
\hline
\end{tabular}

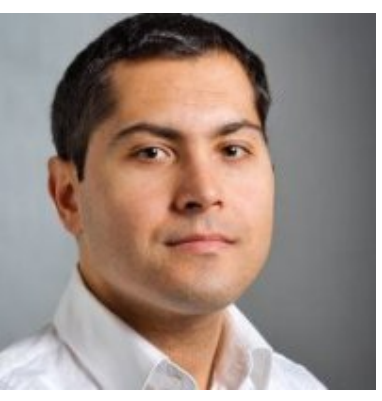

\section{Biographies}

Momir Beljić obtained a master degree in Telecommunication from the University of Novi Sad and currently is a $\mathrm{PhD}$ candidate at Lappeenranta University of Technology. Before starting his $\mathrm{PhD}$ studies, he worked in various companies in the field of computer networks and corporate leadership.

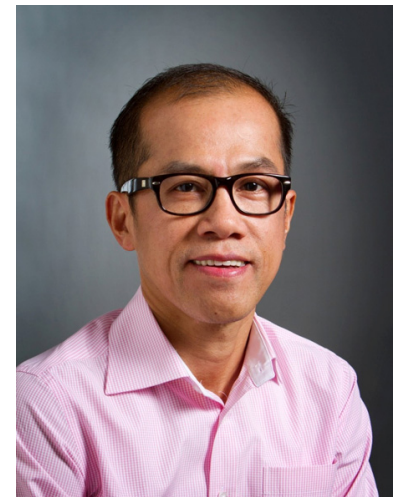

Virgilio Panapanaan, D.Sc. (Tech) is holding an Associate Professor post at Environmental Technology and Management Program in Lappeenranta University of Technology (LUT), Finland. Virgilio is involved both in teaching and research activities of LUT. He teaches courses on Sustainability Studies, Environmental Management and Economics and Corporate Responsibility Management. Research-wise, Panapanaan conducts research on various issues of sustainable development particularly on environmental and social sustainability. Currently, his research projects and involvements are on sustainable innovations (eco-innovations and social innovations), sustainable value creation at the Base of the Pyramid (BoP), and corporate social responsibility (CSR). Panapanaan has published several papers on these issues in peer-reviewed international journals. 


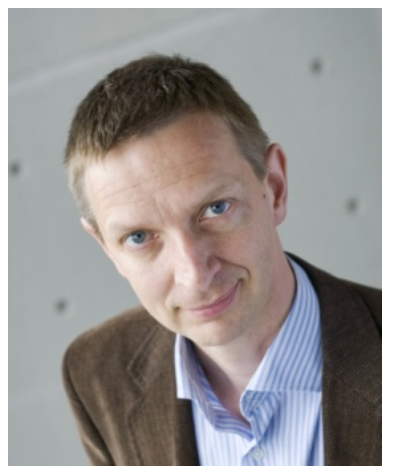

Lassi Linnanen is a Professor of Environmental Economics and Management at Lappeenranta University of Technology, Finland. He received his Master degree from Helsinki University of Technology and $\mathrm{PhD}$ from University of Jyväskylä, Finland. His research interest covers the domain of sustainable development and business strategy.

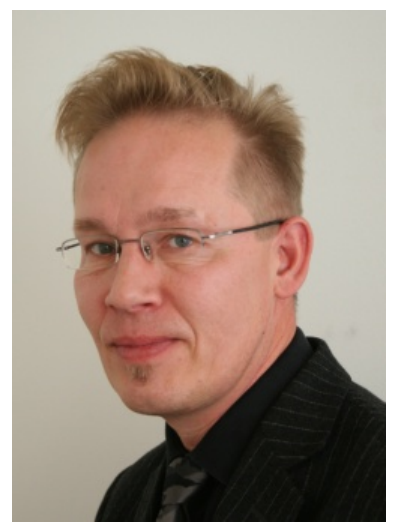

Tuomo Uotila, D.Sc. (Tech.), works as a Professor (Management of Foresight Knowledge) at Lappeenranta University of Technology. He is also an Adjunct Professor (Economic Geography, especially Regional innovation Systems) at Turku University, Department of Geography. Uotila has previously worked as a researcher at Turku School of Economics and Helsinki University of Technology. His current research interests are related to futures research and organizational and regional foresight activities, networked innovation processes, knowledge transfer in networks and absorptive capacity. He has published several papers on these issues in highly ranked international scientific journals. 